\title{
Significance of Material and Ambiance in Content Based Instruction in Improving the Skills of EFL Students
}

\author{
Dr.K.Yugandhar \\ Associate Professor, Department of English, Dilla University, Dilla, Ethiopia, Africa \\ yogi.english@gmail.com
}

\begin{abstract}
Content-based instruction, an English language teaching method focuses on improving language skills by facilitating opportunities to listen, speak, read and write while accommodating learners' choicest subject material. Davies (2003) points out that CBI is a method which emphasizes learning about something rather than learning about language. Of the three models of CBI, Content-theme-based classes are planned to teach about a topic in the target language. The syllabus is structured around themes or topics, with the linguistic elements and communicative activities in the Course work. "In a theme-based course, the content is exploited and its use is maximized for the teaching of skill areas" (Brinton, Snow, and Wesche 1989).
\end{abstract}

The teacher can increase their interest and enthusiasm by facilitating a variety of material in different formats driven by universal language acquisition principles. Students own the responsibility of acquiring the language skills once the subject content is facilitated in conducive ambiance. This method is effective as the appropriate materials are applied in conducive ambiance facilitating opportunities to experiment with the language use. Thus, the blend of language elements and content knowledge is a commendable way to develop learners' English language proficiency by enabling them to participate in complex academic and social situations.

Keywords: Content Based Instruction, Theme Based Model, Appropriate Subject Material, Conducive Ambiance for Language Acquisition.

\section{INTRODUCTION}

Content-based instruction, an English language teaching method that accommodates subject content while developing the students' language skills by facilitating many opportunities to the learning to practice listening, speaking, reading and writing. The idea is originated from the successful Canadian French Immersion Programs and increasingly associated with English language learning. It suggests that teaching / learning discrete language elements and skills is not sufficient to develop accurate knowledge of the language. Davies (2003) points out it is a method which emphasizes learning about something rather than learning about language.

Three models of CBI have been spread in English classes and are used profusely by the professional teachers according to their contexts since Mohan (1979) explored three cases of relations between language teaching and content teaching. 'Sheltered model' blends the expertise of a content specialist and an ESL specialist work together to improve both. 'Adjunct model' tries to acclimatise students to classes with L1 learners under the guidance of English teachers. 'Theme based model' builds upon the students' own interests with the encouragement, guidance and support of English teacher. Contenttheme-based classes are planned to teach about a topic in the target language. The syllabus is structured around themes or topics, with the linguistic elements and communicative activities in the Course work. "In a theme-based course, the content is exploited and its use is maximized for the teaching of skill areas" (Brinton, Snow, and Wesche 1989). Besides, theme-based approach provides coherence and continuity across the skill areas and syllabus. Further, this model is flexible in terms of institutional setting and student proficiency level.

\section{CONTENT-THEME-BASED INSTRUCTION}

Brinton, Snow and Wesche (1989) define CBI as "the integration of particular content with language teaching aims...as well as the concurrent teaching of academic subject matter and second language skills. Accommodating suitable content theme based approach is executed in EFL class to allow students to integrate academic skills like note-taking from texts and lectures and language skills. The teaching learning process has the following extra features besides the regular procedures. 
$>$ Students are presented with authentic reading texts from the subject area, which they are expected to read not only literally but interpretively and critically as well. They are exposed to various material in their choicest areas of subject in English. They choose the content according to their earlier knowledge and language expertise.

$>$ Though the students refer to slightly different material on a subject matter, they are expected to grasp / understand the information. Work sheets prepared by the teacher supports them to produce factual information by negotiating the meaning / ideas from lecture and reading sources.

$>$ Once the students complete the work sheets, they are given language-dependent activities that facilitate them to use language elements. Students are given opportunity to reflect on the material in various language activities like group discussion, thus the receptive skills are assessed while they share their content in the target language.

$>$ Students take many decisions by themselves in the choice of words, sentence construction, and pronunciation. In doing so, they take the responsibility for their learning and using English language. Besides learning the subject matter, they are encouraged to strategically reproduce the subject information at right time compelling the students to use the target language out of passion.

Stoller and Grabe suggested Six T-s approach to build coherence in CBI. These can be successfully adopted in theme based model.

- Themes: The major ideas around which the units are organized are themes determined by taking students' interests, needs and likes, relevance and institutional appropriateness into account.

- Topics: Subunits of themes are topics. A theme may subsume several topics organized / building one topic on the other arranged in a synchronized manner.

- Texts: language in classroom is presented in meaningful texts. Stoller and Grabe (1997) claim that ... students' interest, relevance, and instructional appropriateness, length, coherence, connection to other materials, accessibility, availability, and cost are important.

- Tasks: Students can develop valuable study skills, such as note-taking, summarizing, and extracting key information from texts through tasks. They may also develop skills in synthesizing, problem solving, and critical thinking.

- Transitions: Curricular coherence is provided by transitions. Topics and tasks are linked smoothly by transitions.

- Threads: Another curricular coherence is provided by threads. They are defined by natural linkages across themes. They help students to recycle content, use learning strategies, and to synthesize.

Content-theme-based language class focuses on the exposure to the synchronized teacher's input and peer input and interactions. Accordingly, students assume active, social roles in the classroom that involve interactive learning, negotiation, information gathering and the co-construction of meaning (Lee and VanPatten, 1995). In such classrooms, students learn through doing and are actively engaged in the learning process. They do not depend on the teacher to direct all learning or to be the source of all information. Thus, it is important for teachers to give students voice, especially in the current educational climate, which is dominated by standardization and testing (Simmons and Page, 2010).

\section{CONCEPT OF LEARNER INDEPENDENCE IN CONTENT - THEME-BASED INSTRUCTION}

The syllabus used in theme based model is intended to a type of instruction in which the crucial goal is to teach specific information and content using the language that the learners are also learning. Although the subject matter is of primary and vital importance, language learning occurs concurrently with the content learning. The learners are at the same time language students and learners of whatever content and information is being taught. As compared with the task-based approach of language teaching that is connected with communicative and cognitive processes, content-based language teaching deals with information. This syllabus can be exemplified by assuming a computer science class in which content related to computers is taught in the language the learners need or want to learn, possibly with linguistic adjustment to make the computer science knowledge more understandable. While facilitating the material and conducting the language acquiring activities the following concepts of learner independence are to be considered. 
Firstly, encouraging the concept of learner independence is important. Students improve their linguistic ability through imitating the effective users of the language in self-achievable activities. However, learning can hardly take place unless the students understand that learning is their own responsibility. They achieve the goals of language learning only if they wish to learn by means of active interaction, cooperation and participation with the content and in learning activities. With the guidance and assistance, students monitor their learning process and express their needs explicitly. However, most of the students do not realize that they need to take at least partial responsibility in learning. Although it may take time to promote the students' independence, the effort will pay off. The material used in the activities in encouraging, challenging way paves path for self-study. Once the students understand and accept the concept of learning independence, they will take an active role in self-access and seek for help whenever necessary. Teachers, then, do not have to spend too much time and energy in pushing students to study. They can spare more effort in providing the help to those who really need.

Secondly, to cope with the concept of learner independence, students need to be occasionally allowed to choose the required data, audio or visual material to use in activities / assignments. During the activities / assignments, the teacher needs to discuss with the learners about the composition and time span. Further, they are given freedom to take decisions in using the language while doing an activity and giving a test/assignment. This enables the learners to experiment with the language usage and improves the role of learners in the process of learning. Once they feel that they are responsible for their own learning, their involvement in the language learning rises to the next level.

Thirdly, teachers need to prepare various forms of self-access sheet, worksheets, learning activities, language games, teaching aids, and assessment charts in collaboration with other subject teachers who are expertise in the subject content. It also saves lot of time and energy in the preparation. They can cooperatively work out some interesting and effective language games, feasible communicative activities, and various forms of content that suits to various levels of students. A variety of games, communicative activities, and contests lower down the possible boredom form repetitious drill and practice, or routine, monotonous teaching models. The variety provides not only exciting stimuli both for teachers and students, because people always need a change all the time, especially when you are doing psychological work, but also offers great chance for students to organize, and perform what they have already learned. It is better not to underestimate the effects of such various activities, but, on the other hand, never overuse them either. The magic power of the variety in activities lies in the appropriate use of them. Too much or too little use of them will do harm to the regular, teaching and learning.

Fourthly, students are encouraged to be self-learners from the material collected from real life situations in data, audio and visual formats in the choicest subjects. Spending longer period of time in studying does not necessarily guarantee good achievement. On the contrary, students tend to feel frustrated when the long-time of studying does not bring out the expected score from the test. If such frustration continues, students will be demotivated and become helpless or desperate. Thus, understanding the role of helping students to learn effectively and happily, teachers should recognize the significance of providing various learning strategies to fit students learning styles and needs. When students are properly trained how to learn and become active learners, they can be, then, trained again to be good reviewers. By reviewing the peers' compositions, students become conscious of, and more responsible of learning. By checking these peers' quiz, they can also check their comprehension of the quiz too. Thus, training students to be active learners and helpers, teachers can spare more time and energy to individual attention.

\section{Facilitating Appropriate Material and Conducive Ambiance}

Once the learners are understood that they are responsible for their language proficiency, the teacher can increase their interest and enthusiasm by facilitating a variety of material in different formats. Tomlinson \& Masuhara suggests that the criteria for material development should be clear, accountable, specific and valid to be really useful for language learning. Considering their ideals of effective subject related materials for effective English language teaching / learning the following principles are suggested. 
4.1. The Learners are Exposed to a Rich, Meaningful, and Comprehensible Input of Language in use

In order to acquire the ability to use the language effectively the learners need a lot of experience of the language being used in a variety of different ways for a variety of purposes. They need to be able to understand enough of this input to gain positive access to it and it needs to be meaningful to them. (Krashen, 1999; Long, 1985; Tomlinson, 2010)

\subsection{Engage Learners Both Affectively and Cognitively in the Language Experience}

If the learners do not think and feel whilst experiencing the language, they are unlikely to achieve language acquisition and development. Thinking whilst experiencing language in use helps to achieve the deep processing required for effective and durable learning and it also helps learners to transfer high level skills such as predicting, connecting, interpreting and evaluating. This is true of learners' responses to the content of what they are reading, writing, listening to or saying but the emotions stimulated by the self-access learning experience need to be positive and pleasurable to maximize the learning. (Arnold, 1999; Tomlinson 2011)

\subsection{Language Learners can Benefit from Noticing Salient Features of the Input}

If learners notice for themselves how a particular language item or feature is used they are more likely to develop their language awareness. They are also more likely to achieve readiness for acquisition. Such noticing is most salient when a learner has been engaged in a text and then returns to it to make discoveries about its language use. This is likely to lead to the learner paying attention to similar uses in subsequent inputs and to increase the potential for eventual acquisition. (Schmidt \& Frota, 1986; Tomlinson, 2007)

\subsection{Provide Opportunities to use Language for Communicative Purposes}

Communicating in the target language allows learners to gain feedback on the hypotheses they have developed and on their ability to make use of their hypotheses effectively. If they are interacting, they are also being pushed to clarify and elaborate and they are also likely to elicit meaningful and comprehensible input from their interlocutors. (Swain, 2005)

Besides facilitating the effective subject content driven by universal language acquisition principles, the content must obviously also consider those principles which are specific to the delivery of materials in conducive ambiance to students.

\section{a) The materials should aim to offer learners better learning than a normal course}

The materials should offer more learning time, more experience of the language, more variety of experience of the language, more individual support, and more feedback. Many learners doing language courses spend much of their time focusing on examples of the language and insufficient time experiencing language in use. Materials should not offer them even more examples of the language but should offer more experience of the language in use instead. Materials can and should provide more variety, support, and feedback, especially if they help learners to contribute to the development of materials likely to cater for their needs and wants.

\section{b) The materials should aim to help the students to become truly independent}

Ideally materials should be training learners to become less and less dependent on materials and more capable of gaining from any exposure to the language in use that they experience. One way of doing this is to add a final activity to materials which encourages the learners to seek extra texts and to try to make discoveries from them. Another way is to actually facilitating self-learning subject content.

\section{c) Feedback should acknowledge achievement and encourage improvement}

Often materials provide answer keys. Learners need to be provided the reasons for the choice. They need to acknowledge the achievements of the learners while at the same time providing information, references, suggestions, and further activities which will help them to improve even more. This is not easy with self-access materials but it can be done by the following means.

- be available to learners of the class through communicative tools like chat and e-mail

- provide samples of other learner work to compare with

- keep samples of proficient users' performance on the similar tasks

- facilitate continuation tasks linked to self-evaluation of performance on a task. 
Effective feedback is to be designed to monitor learners' own progress and gains a sense of achievement besides encouraging them to take responsibility for their own learning.

\section{d) Easy and reliable access to the needed materials}

The best self-access materials are to be provided in the class in a convenient manner so that the learners can access to the desired materials. The material gets its value through its accessibility. The learners feel encouraged to spend more time once they realize that the material available in the class is easily reachable to them as per their needs and choices of learning.

\section{CONCLUSION}

Theme based model plays major role in providing the suitable materials and in applying appropriate methods by facilitating various opportunities to experiment with the use of language use. The Language class encourages the students to interact with their choicest subject information and to sharpen his/her language/ communicative abilities. The incentives of the theme based class are autonomy, spirit of learning and using the language, acquiring the ability at one's own pace and the spontaneous feedback during the activities makes the learning faster. Once the learners are involved in self-study from the very beginning of the course work with suitable content in conducive class climate, they can prepare simple projects which require the minimum of the language knowledge. They become accustomed to self-dependence and responsibility for their education. Thus the blend of language elements and content knowledge is a commendable way of facilitating right ambiance using theme based CBI as it increases learners' English language proficiency by enabling them to participate in complex academic and social situations.

\section{REFERENCES}

Amber, Page, Melissa, Simmons (September 2010). "Motivating Students through Power and Choice". English Journal 100 (1): 65-69.

Brinton, D. (2003). Content-based instruction. In D. Nunan (Ed.), Practical English Language Teaching (pp. 199-224). New York: McGraw Hill.

Brinton, D. M., Snow, M. A., \& Wesche, M. B. (1989). Content-based second language instruction. New York: Newbury House.

Chastain, K. "Developing Second - Language Skills." Theory and Practice. Orlando: Harcourt Brace Iovanovich, Inc, 1988.

Grabe, W., \& Stoller, F. L. (1997). Content-based instruction: Research foundations. In M. A. Snow, \& D. M. Brinton (Eds.), The content-based classroom: Perspectives on integrating language and content (pp. 5-21). NY: Longman.

Krashen, D.S. Second Language Acquisition and Second Language Learning. New York: Prentice Hall International 1988.

Snow, M.A.(2001). Content-based and immersion models for second and foreign language teaching. In M. Celce-Murcia (Ed.), Teaching English as a Second or Foreign Language (3rd ed.) (pp. 303-318). Boston, MA: Heinle \& Heinle.

\section{AUTHOR'S BIOGRAPHY}

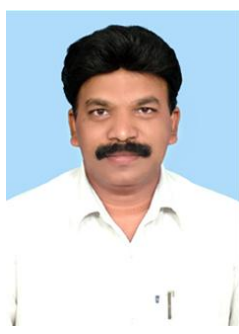

Dr.K.Yugandhar, Associate Professor of English, has received Ph.D. in English from Jawaharlal Nehru Technological University, Hyderabad, India. He has been teaching English language and literature to graduate and post graduate students for the past eighteen years. Most of his research work focuses on interlacing technology with pedagogical concepts to improve the quality of Education in general and English Language Teaching in particular. He received credentials in ELT from Osmania University, Andhra University, Kakatiya University and Central Institute of English and Foreign Language, Andhra Pradesh, India. 